2) N. Hackerman, J.D. Sundbury, J. Electrochem. Soc. 93, 191 (1948).
3) 早怕保昌, 井田郁夫, 本誌 26, 643 (1958).

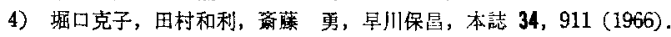

\title{
固体電解質燃料電池用 $\mathrm{ZnO}-\mathrm{Al}_{2} \mathrm{O}_{3}$ および- $\mathrm{ZrO}_{2}$ 系カソード* \\ The $\mathrm{ZnO}-\mathrm{Al}_{2} \mathrm{O}_{3}$ and $-\mathrm{ZrO}_{2}$ Systems as the Cathode Materials \\ for Solid Electrolyte Fuel Cells
}

高橋 武 彦**, 鈴 木 豊**

Takehiko TAKAнAshi, Yutaka SuzUKI

伊 藤 要**, 長谷川 洋**

Kaname Ito, Hiroshi Hasegawa

\section{1 緒言}

高温型固体電解質然料電池の作動温度は, 現在 $1000^{\circ} \mathrm{C}$ 前後で，この温度領域で物理的化学的に安定な電極金属 が少ないために，力ソード (酸素極)アノード(燃料極) ともに白金が使用されている．しかし，白金を使用する ことは経済的および資源的見地から，この種の燃料電池 の実用化を困難とするであるう”。

著者らは，白金に代わる安価なカソード材質を開発す る試みの一つして $\mathrm{ZnO}-\mathrm{Al}_{2} \mathrm{O}_{3}$ 系および $\mathrm{ZnO}-\mathrm{ZrO}$ 系を選び，高温における導電性およびカソードとしての 作動特性を検討した.

$\mathrm{ZnO}-\mathrm{Al}_{2} \mathrm{O}_{3}$ 系は電子導電性酸化物半導体として知方 れており，その導電率については 300 500 $\mathrm{C}$ にわたっ

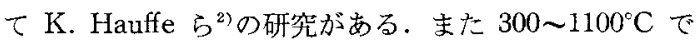

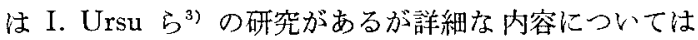
明らかでない. $\mathrm{ZnO}-\mathrm{ZrO}_{2}$ 系は原子佂制御理論”によれ ば $\mathrm{ZnO}-\mathrm{Al}_{2} \mathrm{O}_{3}$ 系と類似の性質が期待されるうえに, $\mathrm{ZrO}_{2}$ 系固体電解質と同一成分 $\left(\mathrm{ZrO}_{2}\right)$ を含むから，こ の電解質に適したカソード材質であるうと予測される。 この系の導電率については M. Bartushkaら が室温〜 $500^{\circ} \mathrm{C}$ (ある組成に対しては $800^{\circ} \mathrm{C}$ ) にわたって測定し ている.しかしこれらの研究は I. Ursu らの研究を 除けば $1000^{\circ} \mathrm{C}$ 前後での導電率を測定していない，それ ゆえまずこれらの系の組成を変化させて $300 \sim 1100^{\circ} \mathrm{C}$ までの導電率を测定した．次に，この測定で良好な導 電率を示した $(\mathrm{ZnO})_{0.97}\left(\mathrm{Al}_{2} \mathrm{O}_{3}\right)_{0.03}$ および $(\mathrm{ZnO})_{0.05}$ $\left(\mathrm{ZrO}_{2}\right)_{0.05}$ の組成をもつ粉末を固体電解質 $\left[\left(\mathrm{ZrO}_{2}\right)_{0.85}\right.$ $(\mathrm{CaO})_{0.15}{ }^{6)},\left(\mathrm{ZrO}_{2}\right)_{0.91}\left(\mathrm{Y}_{2} \mathrm{O}_{3}\right)_{0.09}{ }^{7},\left(\mathrm{CeO}_{2}\right)_{0.75}\left(\mathrm{La}_{2} \mathrm{O}_{3}\right)$

\footnotetext{
* 昭和 40 年 10 月第 6 回管池討論会 (名古屋) 标上《昭和 41 年 4 月電 気化学势会第 33 回大会 (東京) 心七発表.

** 名古屋大学工学部応用化学教室（愛知県名古屋市干種区不老町）
}

$0.25^{8}$ ] に焼き付ける条件党検討した。その際，単味 $\mathrm{ZnO}$ を比較のために焼き付けたが焼き付きは不良であった。 これらに反し, $(\mathrm{ZnO})_{0.97}\left(\mathrm{Al}_{2} \mathrm{O}_{3}\right)_{0.03}$ および $(\mathrm{ZnO})_{0.95}$ $\left(\mathrm{ZrO}_{2}\right)_{0.05}$ の場合は限られた条件の下で焼き付けること ができた. そこでこの両物質をカソードとして電解質に 焼き付けた固体電解質燃料電池を試作し，カソードの作 動特性および安定性を検討したところ，両物質が白金に 代わるカソード材質として十分に使用しうるここがわか った。

\section{2 実験および結果}

\section{$2.1 \mathrm{ZnO}-\mathrm{Al}_{2} \mathrm{O}_{3}$ 系およひ $\mathrm{ZnO}-\mathrm{ZrO}_{2}$ 系の導電率測 定}

2.1 .1 試料作製 試薬特級 $\mathrm{ZnO}$ 粉末に試薬特級 $\mathrm{Al}\left(\mathrm{NO}_{3}\right)_{3} \cdot 9 \mathrm{H}_{2} \mathrm{O}$ 拈よび $\mathrm{Zr}\left(\mathrm{NO}_{3}\right)_{4} \cdot 5 \mathrm{H}_{2} \mathrm{O}$ (原子炉用 $\mathrm{ZrO}_{2}$ 加ら自製）の水溶液を目的量加えて十分にかくは 几混合後, $160^{\circ} \mathrm{C}$ で一夜乾燥し, メノウ乳鉢中で粉砕し $\succ \mathrm{ZnO}-\mathrm{Al}_{2} \mathrm{O}_{3}$ 系は $930^{\circ} \mathrm{C}, \mathrm{ZnO}-\mathrm{ZrO}_{2}$ 系は $950^{\circ} \mathrm{C}$ で 1.5 時間焼成後, 再びメノウ乳錸中で粉砕してから子る い分けし，200メッシュふるい通過粉末を両系の試料粉 末とした.

導電率測定用焼結体の焼成に先きだち単味 $\mathrm{ZnO}$ の昇 華による減量を定性的に測定し焼結温度を検討した。す なわち単味 $\mathrm{ZnO}$ 粉末の $0.2 \mathrm{~g}$ を白金ボート中にはか り取り,一端を封じた孔径 $35 \mathrm{~mm}$, 長さ $1000 \mathrm{~mm}$ の燃 燒管中央に置いて $1000 \sim 1400^{\circ} \mathrm{C}$ の所定の温度でそれぞ れ 1 時問焼成後, ひよう量して減量を求めた。 その結果 注図 1 に示したごとくで， $1400^{\circ} \mathrm{C}$ までは著しい昇莘が 起こらなかった。

両系の試料粉末に成形成として $2.6 \mathrm{wt} \%(\approx 15 \mathrm{vol} \%)$

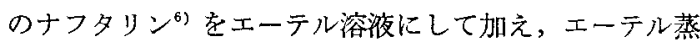
発後, 単動型プレスを用いて円板状（径 $13 \mathrm{~mm}$, 厚 2 
$3 \mathrm{~mm}$ ) に加庄成形（成形圧 $2 \mathrm{ton} / \mathrm{cm}^{2}$ ) し, 高アルミナ

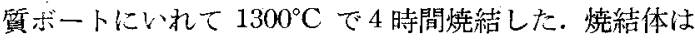
而面に白金ペーストを塗り， $1300^{\circ} \mathrm{C}$ で 1 時間焼き付け て白金を電極とし，導電潆测定用試料にした。

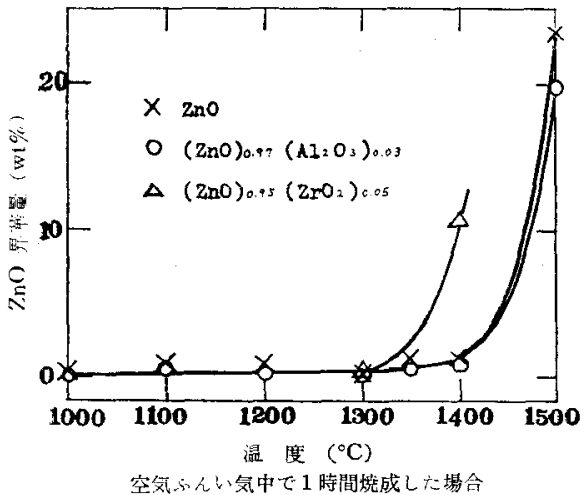

図 1 ZnO 暴華量

2.1 .2 導電率測定 図 2 に示した装置により試料 の直流抵抗を測定 した. 試料は二枚 の白金板ではさま れており，両白金 板からは二本の白 金遒線が出してあ る. 一対の導線加 ら直流を流し，も う一效の導線で電

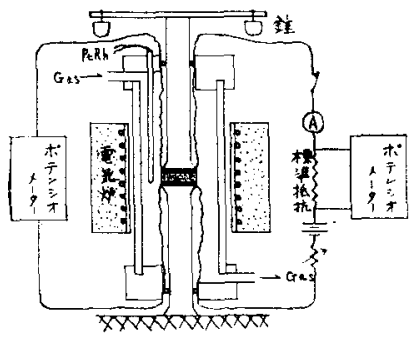

図 2 賆電率測定装置
压降下を測定して抵抗を算出した。電圧の測定にはポテ ンシオメーターを使用した。

測定を開始する前に試料と白金板の間の接触抵抗を少 なくするため温度を $1100^{\circ} \mathrm{C}$ まで上げて数時間保持し， 徐々に温度を下げて測定温度に 0.5〜1 時閒保持したの ち测定を開始した。 各測定とも電流变 化させ(最大 $20 \mathrm{~mA}$ ) オームの法則にした がっていることを確 かめながら测定し た。また熱起電力を 補償するために電流 を正逆両方向に流し て測定した. 500 $1100^{\circ} \mathrm{C}$ までの組成 に刘する空気子んい 気中での抵抗を導電 率に換算して図 3,4 に示した. $1000^{\circ} \mathrm{C}$ 前後ての組成に対
する最大導電率は $(\mathrm{ZnO})_{0.97}\left(\mathrm{Al}_{2} \mathrm{O}_{3}\right)_{0.03}$ 扰よ゙ $(\mathrm{ZnO})_{0.95}$ $\left(\mathrm{ZrO}_{2}\right)_{0.05}$ によって 与えられ，いずれも $5 \mathrm{ohm}^{-1} \mathrm{~cm}^{-1}$ 以上で ある。遒電率に関す る限り，これら画組 成の物質は的金に代 わるカソード材斦と して使用しらること を示している。

導電率に及ぼす酸 素分圧の影響を調べ るため，水分および 炭酸ガスを除去した

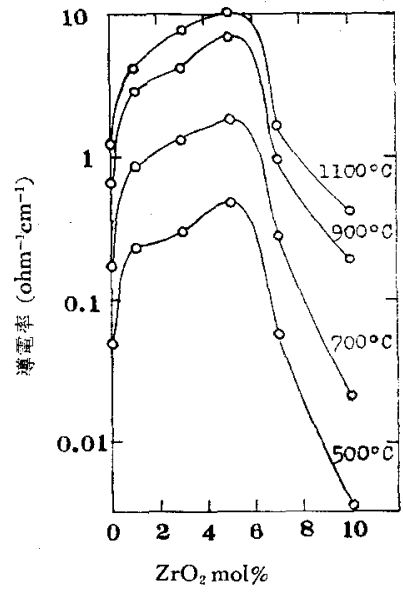

空気的九気中

図 $4 \mathrm{ZnO}-\mathrm{ZrO}_{2}$ 系の導電率 窒素および酸素を混合比を変えてセルに流し（約 $75 \mathrm{cc} /$ min), 3 mol\% $\% \mathrm{Al}_{2} \mathrm{O}_{3}$ および 3 mol\% $\mathrm{ZrO}_{2}$ 試料につ いて導電率を測定した．各酸素分压に $0.25 \sim 2$ 時間保持 したのち，10 分間以上一定の導電率を示すところで測 定を打ち切った。図 5 に結果の一部を示した，酸素中で の尊電率は空気中での值と比べ約 $20 \%$ ほど減少して 浔.

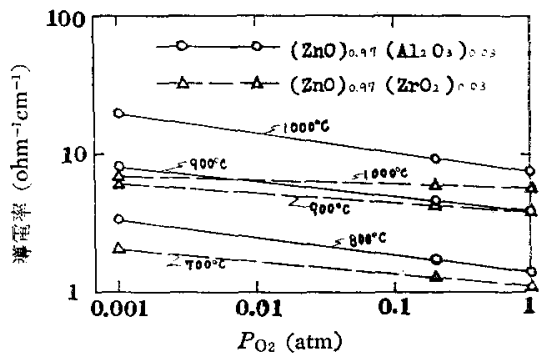

図 5 導電溸に和よぼす酸素分圧の影響

\section{$2.2(\mathrm{ZnO})_{0.97}\left(\mathrm{Al}_{2} \mathbf{O}_{3}\right)_{0.03}$ および}

$(\mathrm{ZnO})_{0.95}\left(\mathrm{ZrO}_{2}\right)_{0.05}$ の固体電解質への焼き付け

2.1 .2 て $(\mathrm{ZnO})_{0.97}\left(\mathrm{Al}_{2} \mathrm{O}_{3}\right)_{0.03}$ および $(\mathrm{ZnO})_{0.95}(\mathrm{Zr}$ $\left.\mathrm{O}_{2}\right)_{0.05}$ が良好な導電率を示したので，以後の実験には この組成（以後両物質と記す）についてのみ実験した.

2.2 .1 焼き付け条件の検討 雨物質を電極として

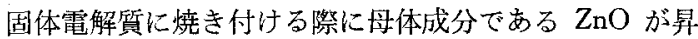
華し，これらの組成が変化する扝それがある，それゆえ 2.1 .1 と同様の手法によって雨物質試料粉末の $\mathrm{ZnO}$ 昇 華量を測定したところ，3 mol\% $\mathrm{Al}_{2} \mathrm{O}_{3}$ は $1400^{\circ} \mathrm{C}$ ま で， $5 \mathrm{~mol} \% \mathrm{ZrO}_{2}$ は $1300^{\circ} \mathrm{C}$ まで著しい昇華が認めら れなかった（図 1 ).

固体電解質に $\left(\mathrm{ZrO}_{2}\right)_{0.85}(\mathrm{CaO})_{0.15},\left(\mathrm{ZrO}_{2}\right)_{0.91}\left(\mathrm{Y}_{2} \mathrm{O}_{3}\right)$ 0.05 および $\left(\mathrm{CeO}_{2}\right)_{0.75}\left(\mathrm{La}_{2} \mathrm{O}_{3}\right)_{0.25}$ を選んで，これらを 自製(6) 8) し，両物質の試料粉末をメタノールと練ってペ 
一ストにして、これを約 $0.3 \mathrm{~mm}$ の厚さに塗布し，種々 の温度で 1 時間焼き付けた. その際, 比較のために $1300^{\circ} \mathrm{C}$ で 1 時間予備焼成した単味 $\mathrm{ZnO}$ 粉末日別に㜔 き付けた。焼き付き状態の良否（良否の判定には，ナイ フェッジで削ってみて簡単にはがれないことを基準にし た）を調べてみたところ表1のような結果となった。こ 机を図 1 の $\mathrm{ZnO}$ 㫒華量一温度曲線と考え合和せると， 著者らの作製した試料粉末についての最適焼き付け温度 は, $3 \mathrm{~mol} \% \mathrm{Al}_{2} \mathrm{O}_{3}$ の場合 $1350^{\circ} \mathrm{C}, 5 \mathrm{~mol} \% \mathrm{ZrO}_{2}$ の場 合は $1300^{\circ} \mathrm{C}$ である(ただし焼き付け時間は 1 時間)。

表 $1 \mathrm{ZnO},(\mathrm{ZnO})_{0.07}\left(\mathrm{Al}_{2} \mathrm{O}_{8}\right)_{0.08}$ 和よび $(\mathrm{ZnO})_{0.95}$ $\left(\mathrm{ZrO}_{2}\right)_{0.05}$ の焼き付き状態

\begin{tabular}{|c|c|c|c|c|}
\hline \multicolumn{5}{|c|}{ 誻过付け㭙間：空気中 $1 \mathrm{hr}$} \\
\hline 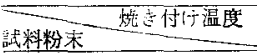 & $1250^{\circ} \mathrm{C}$ & $1300^{\circ} \mathrm{C}$ & $1350^{\circ} \mathrm{C}$ & $1400^{\circ} \mathrm{C}$ \\
\hline $\begin{array}{l}\mathrm{ZnO} 1300^{\circ} \mathrm{C} 1 \mathrm{hr} \\
\text { 予借烓成 }\end{array}$ & $\times$ & $x$ & $\times$ & $x$ \\
\hline $\begin{array}{l}(\mathrm{ZnOO})_{0.97}\left(\mathrm{Al}_{2} \mathrm{O}_{3}\right)_{0.03} \\
930^{\circ} \mathrm{C} 1.5 \mathrm{hr}\end{array}$ & $x$ & $\triangle$ & 0 & $\Delta$ \\
\hline $\begin{array}{l}(\mathrm{ZnO})_{0.95}\left(\mathrm{ZrO}_{2}\right)_{0.05} \\
950^{\circ} \mathrm{C} 1.5 \mathrm{hr}\end{array}$ & $\triangle$ & 0 & 0 & $\triangle$ \\
\hline \multicolumn{5}{|c|}{ O 良好 } \\
\hline
\end{tabular}

この最適燒き付け温度注電解質の種類汇無関倸であっ たが $\mathrm{ZnO}$ 単味の場合に注粉末粒子相互の焼結が著し

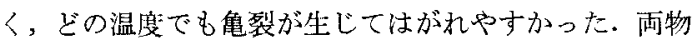
質の場合も最適焼き付け温度を越えた温度では $\mathrm{ZnO}$ 単 味の場合と同様の現象を示した。

最適焼き付け策件下での焼き付き状況は両物質とも多 孔性で，簡単にナイフで削ることができた．しかし電解 質上の境界面近くでは比較的強固に焼き付いていた。 た，顕微鏡観察の結果ては電解質と反応を起こしている 栐子江諗的られなかった。

2.2 .2 電解質中への $(\mathrm{ZnO})_{0.97}\left(\mathbf{A l}_{2} \mathbf{O}_{3}\right)_{0.03}$ および $(\mathbf{Z n O})_{0.95}(\mathbf{Z r O})_{0.05}$ 構成成分の搪散 雨物質々電解 質との反応をさらに詳しく倹乱するために $\left(\mathrm{ZrO}_{2}\right)_{0.85}$ $(\mathrm{CaO})_{0.15}$ を電解質に用いた場合について耐物質構成成 分の電解質中一の拉散の程度を重量法により検討した。

両物質の焼結体 (2 ton $/ \mathrm{cm}^{2}$ で加圧成形してから $1300^{\circ} \mathrm{C}$ で 1 時間焼結) と電解質とを重社合わせて（見かけ接触 泊積 $\approx 1 \mathrm{~cm}^{2}$ ), 空気中 $1300^{\circ} \mathrm{C}$ で 14 時間焼成したとこ ろ，焼き付きが起こらなかった。そこで雨物質と電解質 彭ひら量したところ $(\mathrm{ZnO})_{0.97}\left(\mathrm{Al}_{2} \mathrm{O}_{3}\right)_{0.03}$ は $0.69 \%$ ， $(\mathrm{ZnO})_{0.95}\left(\mathrm{ZrO}_{2}\right)_{0.05}$ 汁 $0.60 \%$ 重量が減少していたにも かかわらず電解質の重量は変化していなかった。こ机ら の重量減少沬 $\mathrm{ZnO}$ の昇華に上るものであるう。したが 。て両物質構成成分（特飞要鉛）注電解質中一ほとんど 拉散していないものと考えられ，これらが電解質の酸素 イオン輸率に悪影響を及ばすとは思われない。

\section{$2.3(\mathrm{ZnO})_{0.97}\left(\mathrm{Al}_{2} \mathbf{O}_{3}\right)_{0.03}$ および}

$(\mathbf{Z n O})_{\mathrm{n} .95}\left(\mathbf{Z r O}_{2}\right)_{0.05}$ のガソードとしての作動特性 阿物资をカソードとし，アノードには徉来ど㧍り白金。
を使用した酸素一水素然料電池を試作し，両物僙のカソ ードとしての特性を検討した。

電解質に $\left(\mathrm{ZrO}_{2}\right)_{0.85}(\mathrm{CaO})_{0.15}$ 㧍よび $\left(\mathrm{CeO}_{2}\right)_{0.75}\left(\mathrm{La}_{2}\right.$ $\left.\mathrm{O}_{3}\right\rangle_{0.25}$ を用いて図 6.1 の上らに電極を焼き付け，ガス 漏れおよび局部電池作用の影響を防ぐために電極から離 れた位置に白金製パッキングを施し，照合電極用の白金 線を巻き付けて図 6.2 のよう電池を構成した。カカンー

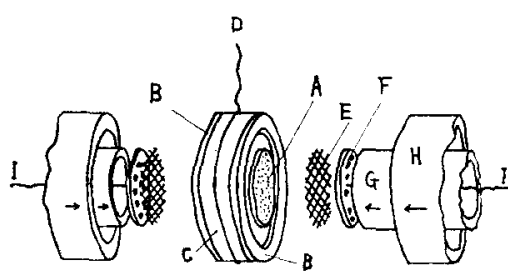

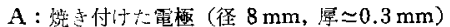
B : ヒ毛金製ハッキンク
$\mathrm{C}$ : 固体電解質（径 $13 \mathrm{~mm}$, 厚 $2 \sim 3 \mathrm{~mm}$ )
$\mathrm{D}:$ 照合電極， E：白金製ガーゼ，
$\mathbf{F}$ : 白金製集電板， $\mathrm{G}, \mathrm{H}$ ：高アルミナ琶磁整管
I：的金導線

图 6.1 電 池 $\sigma$ 满 造

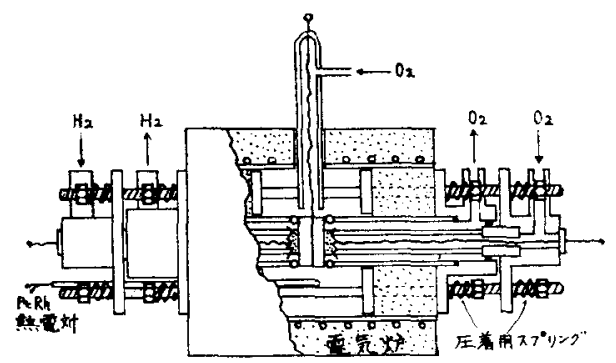

困6.2 電池の箱造

ドおよび照合電極側には酸素をそれぞれ $70 \mathrm{cc} / \mathrm{min}, 100$ cc/min の流速で流し，アノード側には $20^{\circ} \mathrm{C}$ で水蒸気 飽和させた水素を $70 \mathrm{cc} / \mathrm{min} の$ 流速で流した. 分極 特性の測定にはコミュテーター法を用いて IR 降下を除 いた。四 $7 ， 8$ にカンードの分極特性を白金を用いた場 合上比較して示した，分極特性に関しても両物筫が 800

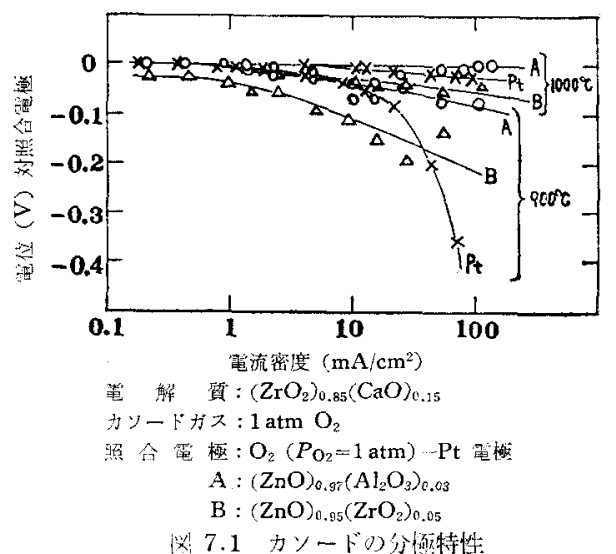




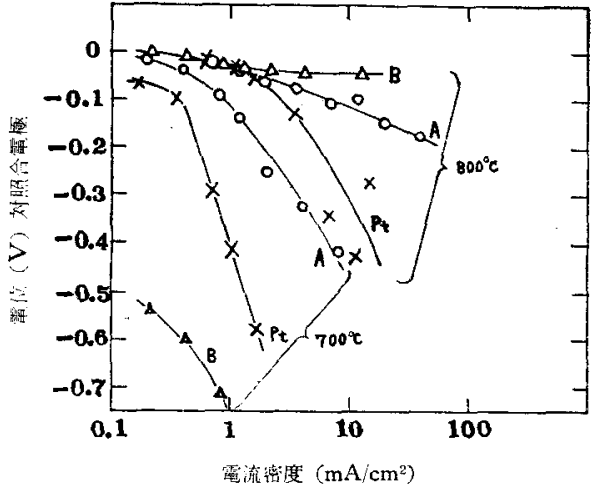

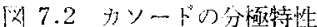

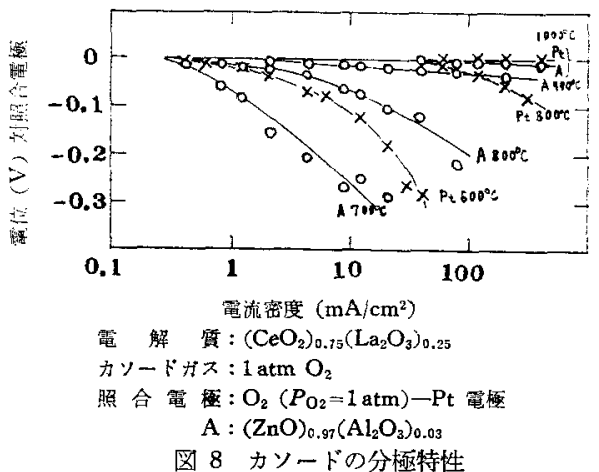

〜 $1000^{\circ} \mathrm{C}$ において十分に白金に代わりうることが認め られるであろう。

電極ししての安定性を試 す目的で図 9 に示したよう な熱衝撃を 8 サイクル与え て, 1 サイクルごとに分極 特性および内部抵抗を測定 したところ，ほとんど異状 は諗められなかった。また これら雨物質の電解質から

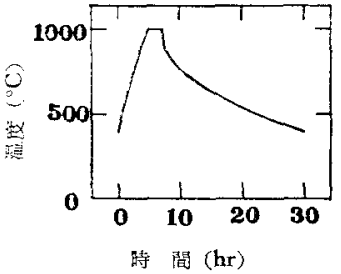

図 9 熱衡慗波形
の脱落も観察されなかった.

試験的に水素極として 使用してみたところ, $\mathrm{ZnO} \mathrm{が}$ 昇華して破損した。

\section{3 考察}

\section{$3.1 \mathrm{ZnO}-\mathrm{Al}_{2} \mathrm{O}_{3}$ 系およひ $\mathrm{ZnO}-\mathrm{ZrO}_{2}$ 系の導電率に} วいて

両采とも一定温度において最大導電率を与える組成は 温度とともに $\mathrm{Al}_{2} \mathrm{O}_{3}$ および $\mathrm{ZrO}_{2}$ の高濃度側に移動し ている(図 3，4).これは $\mathrm{ZnO}$ 中へ $\mathrm{Al}_{2} \mathrm{O}_{3}$ および $\mathrm{ZrO}_{2}$ がドナ一として固溶寸る際に固溶限界が存在し，この固 溶限界が温度とともに $\mathrm{Al}_{2} \mathrm{O}_{3}$ および $\mathrm{ZrO}_{2}$ の高濃度側 へ移動するためであろう。しかしながら，その詳紐につ いては明らかでない。
$3.2(\mathrm{ZnO})_{0.97}\left(\mathbf{A l}_{2} \mathbf{O}_{3}\right)_{0.03}$ およひ $(\mathbf{Z n O})_{0.95}\left(\mathrm{ZrO}_{2}\right)$ 0. 25 の固体電解買への暁き付き機棈について

1) $\mathrm{ZnO}$ 単味の場合には $\mathrm{ZnO}$ 粒子相互の焼結が著し く，電解質からはがれやすい，2) $\mathrm{Al}_{2} \mathrm{O}_{3}$ および $\mathrm{ZrO}_{2}$ をドープした場合には最適焼き付け温度が存在し，その 温度が電解翼の種類に依存しない.3） $\mathrm{Al}_{2} \mathrm{O}_{3}$ および $\mathrm{ZrO}_{2}$ 去ドープした場合でも最適焼き付け温度を越えた 場合には 1 ) と同様の現象を生じる，以上 1)〜3)の現 象は, $\mathrm{ZnO} し(\mathrm{ZnO})_{0.97}\left(\mathrm{Al}_{2} \mathrm{O}_{3}\right)_{0.03}$ および $(\mathrm{ZnO})_{0.95}$ $\left(\mathrm{ZrO}_{2}\right)_{0.05}$ の各粒子相互の焼結速度の差に関連があると 考えられる。

$\mathrm{ZnO}$ は次式によりフレンケル型の格子久陷を生ずる とされている。

$$
\begin{aligned}
& \mathrm{ZnO} \rightleftharpoons \mathrm{Zn}_{i}{ }^{+}+e+1 / 2 \mathrm{O}_{2} \\
& \mathrm{ZnO} \rightleftharpoons \mathrm{Zn}_{i}{ }^{2+}+2 e+1 / 2 \mathrm{O}_{3}
\end{aligned}
$$

( $i$ は格子間位置にあることを示す)。また $\mathrm{Al}_{2} \mathrm{O}_{3}$ およ び $\mathrm{ZrO}_{2}$ がドープされるよ（3)，(4) 式により電子が生 成すると考えられている。

$$
\mathrm{Al}_{2} \mathrm{O}_{3} \rightleftharpoons 2 \mathrm{Al}^{3+}\left(\mathrm{Zn}^{2+}\right)+2 e+2 \overline{\mathrm{ZnO}}+1 / 2 \mathrm{O}_{2}
$$

$$
\mathrm{ZrO}_{2} \rightleftharpoons \mathrm{Zr}^{4}\left(\mathrm{Zn}^{2+}\right)+2 e+\overline{\mathrm{ZnO}}+1 / 2 \mathrm{O}_{2}
$$
$\left(\mathrm{Al}^{3+}\left(\mathrm{Zn}^{2+}\right), \mathrm{Zr}^{4+}\left(\mathrm{Zn}^{2+}\right)\right.$ は格子点の $\mathrm{Zn}^{2+}$ と置換 $\mathrm{L}$ た $\mathrm{Al}^{3+}$ および $\mathrm{Zr}^{4+}$ を示し， $\overline{\mathrm{ZnO}}$ は置換された $\mathrm{Zn}^{2+}$ が新しい格子点に移動した状態を示す)。（3），(4) 式に より生じた電子は (1)，(2) 式の平衡を左へ移動させ, 格子間亜鉛が減少寸る，したがって“焼結の際の物質移 動が格子間亜鉛による” 9)ものとすれば，焼結速度が減 少することになり，上記の両物質の場合は $\mathrm{ZnO}$ 巣味の 場合よりも同一時間内の粒子相互の焼結が弱くなり表 2 に示すように収縮率が小さく，電解質との焼き付きがー 様に保たれ電解質と両物質との熱膨脹の差による空力ひ ずみが緩和されて，はがれることなく狫き付いているも のと考えられる.この機構の妥当性を立証するために $1300^{\circ} \mathrm{C}$ で 1 時間予借焼成した単味 $\mathrm{ZnO}$ と, $(\mathrm{ZnO})_{0.97}$ $\left(\mathrm{Al}_{2} \mathrm{O}_{3}\right)_{0.03}$ および $(\mathrm{ZnO})_{0.95}\left(\mathrm{ZrO}_{2}\right)_{0.05}$ の試料粉末を 加圧成形し， $1300^{\circ} \mathrm{C}$ で 1 時間焼成して，その際の体積 および見かけ密度の変化を測定した（表2）。また，これ

\begin{tabular}{|c|c|c|c|}
\hline & \multirow{2}{*}{ 体積収稀率 } & \multicolumn{2}{|c|}{ 克か心㟆度 } \\
\hline & & 加生成形体 & 烧 結 体 \\
\hline $\begin{array}{l}Z \mathrm{nO} \\
1300^{\circ} \mathrm{C} 1 \mathrm{hr} \text { 予償焼成 }\end{array}$ & $33.9 \%$ & $3.55 \mathrm{~g} / \mathrm{cm}^{3}$ & $5.37 \mathrm{~g} / \mathrm{cm}^{3}$ \\
\hline $\begin{array}{l}(\mathrm{ZnO})_{0.97}\left(\mathrm{Al}_{2} \mathrm{O}_{3}\right)_{0.03} 930^{\circ} \mathrm{C} \\
1.5 \mathrm{hr}\end{array}$ & 16.3 & 3.35 & 4.00 \\
\hline $\begin{array}{l}(\mathrm{ZnO})_{0.45}\left(\mathrm{ZrO}_{2}\right)_{0.05} 950^{\circ} \mathrm{C} \\
1.5 \mathrm{hr}\end{array}$ & 9.4 & 4.02 & 4.44 \\
\hline
\end{tabular}
ら焼結体と $\mathrm{ZrO}_{2}$ 系電解質の熱膨脹を測定した(図 10). 表 2 加王成形体の焼結による体積打よび見かけ密度の変化 成形生 : 4 ton $/ \mathrm{cm}^{2}, 1300^{\circ} \mathrm{C}=1$ 時間炾絬

$\left(\left(\mathrm{ZrO}_{2}\right)_{0.85}(\mathrm{CaO})_{0.15}\right.$ および $\left(\mathrm{ZrO}_{2}\right)_{0.91}\left(\mathrm{Y}_{2} \mathrm{O}_{3}\right)_{0.09}$ の

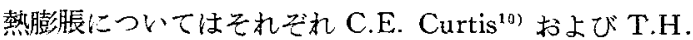




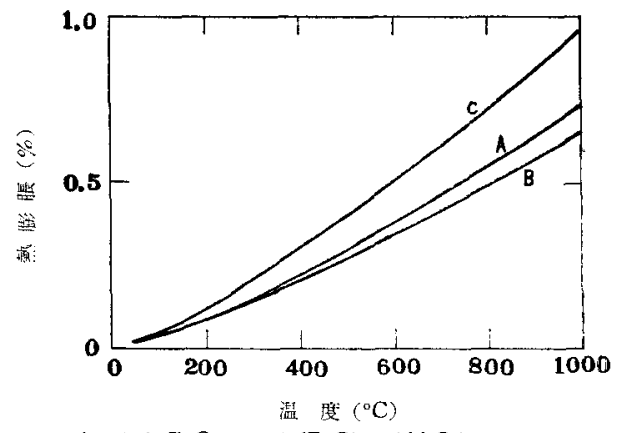

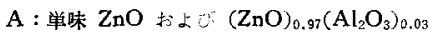

B : $(\mathrm{ZnO})_{0.95}\left(\mathrm{ZrO}_{2}\right)_{0.05}$

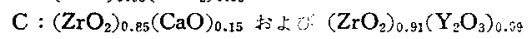
温度上景速度 $: 7.5^{\circ} \mathrm{C} / \mathrm{min}$

図 10 熱膨脹 曲線

Nielsenら ${ }^{11)}$ の研究があり, 著者らの測定值とよく一致 している). 表 2 に示したごとく, $\mathrm{Al}_{2} \mathrm{O}_{3}$ および $\mathrm{ZrO}_{2}$ 在ドープした場合は収縮率が著しく減少しており, 明ら かに焼結しにくいことを示している。また図 10 からは 篹咥 $\mathrm{ZnO}$ と $(\mathrm{ZnO})_{0.97}\left(\mathrm{Al}_{2} \mathrm{O}_{3}\right)_{0.03}$ および $(\mathrm{ZnO})_{0.95}$ $\left(\mathrm{ZrO}_{2}\right)_{0.05}$ の熱膨脹に大きな差がないが，電解翼とこれ らの物質との間にはかなりの差があることがわかる。こ のように電解質と $(\mathrm{ZnO})_{0.97}\left(\mathrm{Al}_{2} \mathrm{O}_{3}\right)_{0.03}$ および $(\mathrm{ZnO})$ ${ }_{0.95}\left(\mathrm{ZrO}_{2}\right)_{0.05}$ の間に比較的大きな熱膨脹の差が存在す るにもかかわらず，これら両物質は焼き付き，単味 $\mathrm{ZnO}$ ははがれやすいことから前記の機構の妥当性が支持され るものと考えられる。

両物質と電解質との結合は両物質の母体成分である $\mathrm{ZnO}$ と電解質の構成成分とのごく少量が固溶するため であろう. $(\mathrm{ZnO})_{0.95}\left(\mathrm{ZrO}_{2}\right)_{0.05}$ 乙 $\mathrm{ZrO}_{2}$ 系電解質の場 合には電解質中の $\mathrm{Zr}^{4+}$ が $\mathrm{ZnO}$ 中人抬散しても良さそ らであるが，電解質が約 $2000^{\circ} \mathrm{C}$ で焼結してあるため， 電解質の表面エネルギーが小さく $1300^{\circ} \mathrm{C} 1$ 時閐程度の 焼き付けでは固溶しにくいであるらと考えられる。

\section{3 カソードとしての作動特性について}

図7，8の分極特性から $800 \sim 1000^{\circ} \mathrm{C}$ において十分に 白金に代わるカソード材質と成りらる。この温度範囲で は $(\mathrm{ZnO})_{0.97}\left(\mathrm{Al}_{2} \mathrm{O}_{3}\right)_{0.03}$ および $(\mathrm{ZnO})_{0.95}\left(\mathrm{ZrO}_{2}\right)_{0.05}$ 中 の $\mathrm{ZnO}$ はほとんど昇華せず，長期の使用に耐えるもの と考えられる。またアノードとして使用できない理由は 3.2 (1)，(2) 式からもわかるように, 酸素分压の減 少によって平衡が右辺にかたより， $\mathrm{ZnO}$ が分解するた わで, $\mathrm{ZnO}$ の本質的性質である。

\section{4 総括}

1. $\mathrm{ZnO}_{-} \mathrm{Al}_{2} \mathrm{O}_{3}$ 系および $\mathrm{ZnO}-\mathrm{ZrO}_{2}$ 系の導電率を $300 \sim 1100^{\circ} \mathrm{C}$ にわたって测定し, $1000^{\circ} \mathrm{C}$ 前後における 組成に対する最大導電率が $(\mathrm{ZnO})_{0.97}\left(\mathrm{Al}_{2} \mathrm{O}_{3}\right)_{0.03}\left(1000^{\circ} \mathrm{C}\right.$ 空気ふんい気中において $\left.9.5 \mathrm{ohm}^{-1} \mathrm{~cm}^{-1}\right)$ および $(\mathrm{ZnO})$ ${ }_{0.95}\left(\mathrm{ZrO}_{2}\right)_{0.05}\left(1000^{\circ} \mathrm{C}\right.$ 空気ふんい気中に打いて 8.8 $\left.\mathrm{ohm}^{-1} \mathrm{~cm}^{-1}\right)$ によって与えられることを明らかにした。

2. $(\mathrm{ZnO})_{0.97}\left(\mathrm{Al}_{2} \mathrm{O}_{3}\right)_{0.03}\left(930^{\circ} \mathrm{C} て ゙ \quad 1.5\right.$ 時間予備焼 成) 㧍よび $(\mathrm{ZnO})_{0.95}\left(\mathrm{ZrO}_{2}\right)_{0.05}\left(950^{\circ} \mathrm{C}\right.$ で 1.5 時間子 催焼成) の粉末を固体電解質 $\left(\left(\mathrm{ZrO}_{2}\right)_{0.85}(\mathrm{CaO})_{0.15}\right.$, $\left.\left(\mathrm{ZrO}_{2}\right)_{0.91}\left(\mathrm{Y}_{2} \mathrm{O}_{3}\right)_{0.09},\left(\mathrm{CeO}_{2}\right)_{0.75}\left(\mathrm{La}_{2} \mathrm{O}_{3}\right)_{0.25}\right)$ に焼き付 け，その焼き付け条件を検討して $(\mathrm{ZnO})_{0.97}\left(\mathrm{Al}_{2} \mathrm{O}_{3}\right)_{0.03}$ は $1350^{\circ} \mathrm{C}$ で, $(\mathrm{ZnO})_{0.95}\left(\mathrm{ZrO}_{2}\right)_{0.05}$ は $1300^{\circ} \mathrm{C}$ でそれ ぞれ 1 時間焼成することによりはがれることなく焼き付 くことを明らかにした．この焼き付け条件はこれら雨物 質と電解質の熱膨脹の差にあまり関係なく，単味 $\mathrm{ZnO}$ がいずれの温度でも焼き付きが不良であることから，こ れら両物質粉末粒子相互閒の焼結速度が燒き付き機構に 大きく影響していることを推定した。

3. $(\mathrm{ZnO})_{0.97}\left(\mathrm{Al}_{2} \mathrm{O}_{3}\right)_{0.03}$ および $(\mathrm{ZnO})_{0.95}\left(\mathrm{ZrO}_{2}\right)_{0.05}$ 老固体電解質として電解韻に焼き付け, 高温型固体電解 質燃料電池を試作し，その電極としての特性および安定 性を検討した結果, $800 \sim 1000^{\circ} \mathrm{C}$ において白金に代わる カソード材翼として十分に使用しらることを明らかにし た.

(昭 $41-6-16$ 受理)

\section{文献}

1) J.I. Slaughter, J.J. Gilvarry, Electrochem. Tech. 2, 249 (1964).

2) K. Hauffe, A.L. Vierk, Z. Physik. Chem. 196, 160 (1950).

3) I. Ursu, F. Puskas, V. Cristea, Rev. Phys. Acad. Rep. Populaire Roumaine 1, 277 (1962); C.A. 58, 6300 C (1963).

4) E.J.W. Verway, P.W. Haaijman, F.C. Romeijn, G.W. Osterhaut, Philips Res. Rep. 5, 173 (1950).

5) M. Bartushka, N.A. Batrakov, J. Applied Chem. USSR 36, 699 (1963); Translated from Zhurnal Obshchei Khimii 36, 724 (1963).

6) 高橋武㝘, 鈴木豊, 本䛰 34. 887 (1966).

7) D.W. Strickler, W.G. Carlson, J, Am, Ceram. Soc. 47, 122 (1964).

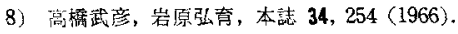

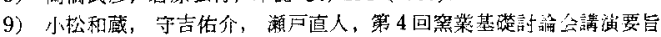
集, 64 員 (1966).

10) C.E. Curtis, J. Am. Ceram. Soc. 30, 180 (1947).

11) T.H. Nielsen, M.H. Leipold, J. Am. Ceram. Soc. 47, 155 (1964). 